\title{
Burkholderia caribensis sp. nov., an exopolysaccharide-producing bacterium isolated from vertisol microaggregates in Martinique
}

\author{
Wafa Achouak, ${ }^{1}$ Richard Christen, ${ }^{2}$ Mohamed Barakat, ${ }^{1}$ \\ Marie-Hélène Martel ${ }^{3}$ and Thierry Heulin ${ }^{1}$
}

Author for correspondence: Wafa Achouak. Tel: +334422549 61. Fax: + 33442256648 .
e-mail: wachouak@cea.fr

1 DSV-DEVM, Laboratoire d'Ecologie Microbienne de la Rhizosphère, UMR 163 CNRS-CEA, CEA Cadarache, F-13108 Saint Paul-lezDurance, France

2 CNRS ESA 2077 and Université Pierre et Marie Curie, Observatoire Océanologique, Station Zoologique, F-06230 Villefranche-sur-mer, France

3 Centre de Pédologie Biologique du CNRS, UPR 6831 Associée à l‘Université de Nancy I, BP 5, F-54501 Vandœuvre-les-Nancy Cedex, France

\begin{abstract}
Twenty-one exopolysaccharide-producing strains were isolated from the 5-20 $\mu \mathrm{m}$ fraction of a vertisol in the south-east of the island of Martinique in the French West Indies. Although these strains were phenotypically identified as Burkholderia cepacia or as Burkholderia glathei using BIOLOG microplates, they did not cluster genotypically by amplified rDNA restriction analysis (ARDRA) with any described Burkholderia species. A phylogenetic analysis revealed that the rrs (16S rDNA) sequences of three representative strains clustered in a single branch within the genus Burkholderia and distantly from all of the previously described species of Burkholderia for which rrs sequences were available. DNA-DNA hybridization data as well as phenotypic analyses indicated that the 21 isolates represented a single and new species for which the name Burkholderia caribensis sp. nov. is proposed (type strain MWAP64 ${ }^{\top}=$ LMG 18531').
\end{abstract}

Keywords: Burkholderia caribensis sp. nov., vertisol microaggregate, rrs analysis, DNA-DNA hybridization, phenotypic analysis

\section{INTRODUCTION}

Almost 80 years after the first description of the genus Pseudomonas (Migula, 1894), this genus was divided into five groups (Palleroni et al., 1973). This division was based mainly on extensive phenotypic studies, and DNA-rRNA and DNA-DNA hybridization experiments (De Vos et al., 1985; Palleroni et al., 1973; Palleroni, 1984, 1992). In a recent review on analysis of rrs (16S rDNA) sequences, it was shown that several sequences of species formerly described as Pseudomonas must be distributed to three of the five subclasses of the Proteobacteria (Kersters et al., 1996). The $\gamma$ subclass includes the authentic genus Pseudomonas that contains the type species Pseudomonas aeruginosa and related species such as Pseudomonas fluorescens.

Abbreviations : ARDRA, amplified rDNA restriction analysis; EPS, exopolysaccharide.

GenBank accession numbers for the rrs sequences reported in this paper are Y17009 (strain MWAP64'), Y17010 (strain MWAP71), Y17011 (strain MWAP84) and Y17052 (B. glathei strain LMG 14190').
The $\alpha$-subclass includes several misnamed Pseudomonas species. Two of these species were transferred to the new genus Brevundimonas (Segers et al., 1994) as Brevundimonas diminuta and Brevundimonas vesicularis, and Pseudomonas paucimobilis was transferred to the genus Sphingomonas (Yabuuchi et al., 1990). The family Comamonadaceae, including the genera Acidovorax, Comamonas and Hydrogenophaga, belongs to the $\beta$-subclass together with the genera Burkholderia (Yabuuchi et al., 1992) and Ralstonia (Yabuuchi et al., 1995).

Using a polyphasic taxonomy approach (Brett et al., 1998; Gillis et al., 1995; Urakami et al., 1994; Vandamme et al., 1997; Viallard et al., 1998; Yabuuchi et al., 1992; Zhao et al., 1995), the genus Burkholderia was recently restricted to 17 species, including a newly described root-associated nitrogen-fixing species Burkholderia vietnamiensis (Gillis et al., 1995), other rootassociated species Burkholderia vandii (Urakami et al., 1994) and Burkholderia graminis (Viallard et al., 1998), and the recently described Burkholderia multivorans (Vandamme et al., 1997) and Burkholderia thailan- 
densis (Brett et al., 1998). This genus is clearly separated from Ralstonia, which includes Ralstonia pickettii (type species), Ralstonia (formerly Pseudomonas) solanacearum and Ralstonia (formerly Alcaligenes) eutropha (Yabuuchi et al., 1995).

During the last 10 years, several laboratories have focused their attention on Burkholderia cepacia (type species) due to its abundance in soil, in the plant rhizosphere and in clinical habitats (Hebbar et al., 1992a; Yohalem \& Lorbeer, 1994). These studies were stimulated by a semi-selective medium (PCAT) (Lumsden \& Sasser, 1986) which facilitates the screening of strains for their ability to degrade polycyclic aromatic hydrocarbons (Mueller et al., 1997) or for their potency to antagonize soil-borne phytopathogens (Hebbar et al., 1992b). Besides the ability to grow on PCAT medium, phenotypic identification (e.g. by GCFAME and BIOLOG microplates) and genotypic identification (e.g. by $r r s$ sequencing and/or DNADNA hybridization) are needed to clarify the taxonomic position of many strains grouped with $B$. cepacia (Mueller et al., 1997).

The objective of this study was to identify bacterial populations that are responsible for the formation of microaggregates in a vertisol on the island of Martinique. Vertisols are characterized by a very high clay content. In these soils, microaggregation results mainly from the fact that bacterial colonies embedded in their exopolysaccharides (EPS) are covered with clay particles (Tisdall, 1994). To isolate these microaggregate-forming bacteria, we prepared a soil fraction rich in microaggregates $(5-20 \mu \mathrm{m})$ and selected bacteria for their EPS production. The phylogenetic position of the major EPS-producing bacterial species isolated from this soil fraction was determined according to rrs sequence analysis. To address the question of their taxonomic position, amplified rDNA restriction analysis (ARDRA), DNA-DNA hybridization and phenotypic analysis were performed.

\section{METHODS}

Strain isolation. Samples from bulk vertisol were collected in the south-east of the island of Martinique in the French West Indies. The site has been under permanent grassland (Digitaria decumbens) vegetation.

EPS-producing bacteria were isolated from the 5-20 $\mu \mathrm{m}$ fraction on sugar-enriched media. Physical soil fractionation was done as described by Kabir et al. (1994). Several carbohydrates (glucose, sucrose, mannitol, sorbitol, xylose, mannose, arabinose and maltose) were used at high concentration $\left(20 \mathrm{~g} \mathrm{l}^{-1}\right)$ as carbon source for bacterial growth and EPS synthesis. The strains investigated in this study and their origin are listed in Table 1. The type strain of $B$. graminis C4D1M was provided by J. Balandreau (Viallard et al., 1998).

Growth conditions and biochemical characterization. The strains were purified on trypticase soy agar (TSA; Difco). They were grown overnight on modified LB medium $\left(1^{-1}\right.$ : $10 \mathrm{~g}$ Tryptone, $5 \mathrm{~g}$ yeast extract, $5 \mathrm{~g} \mathrm{NaCl}$ ) at $28^{\circ} \mathrm{C}$ and phenotypically identified with BIOLOG GN microplates and Microlog release 3.5 software. To increase the number of biochemical characters, BIOLOG GP microplates for Gram-positive bacteria and API 20 NE strips (bioMérieux) were also used.

DNA amplification. Ten microlitres of water-washed suspension of cultures $\left(\mathrm{OD}_{590} 0 \cdot 5\right)$ were used for PCR amplification. $\operatorname{rrs}(16 \mathrm{~S}$ rDNA) genes were amplified using a pair of universal primers $(f d l$ and $r d l)$ corresponding to positions 8-27 and 1524-1540, respectively, on the Escherichia coli rrs sequence. The reaction mixture containing bacterial cells was heated at $95^{\circ} \mathrm{C}$ for $4 \mathrm{~min}$ before the addition of thermoresistant DNA polymerase. PCR consisted of 30 cycles (denaturation at $94{ }^{\circ} \mathrm{C}$ for $1 \mathrm{~min}$, annealing at $55^{\circ} \mathrm{C}$ for $1 \mathrm{~min}$ and extension at $72^{\circ} \mathrm{C}$ for $2 \mathrm{~min}$ ). The final extension was at $72^{\circ} \mathrm{C}$ for $3 \mathrm{~min}$.

Amplified rDNA restriction analysis (ARDRA). The amplified rrs genes were analysed by restriction digestion with 12 restriction enzymes $(A l u \mathrm{I}, C f o \mathrm{I}, D d e \mathrm{I}, H i n \mathrm{II}, T a q \mathrm{I}, H a e I I I$, MspI, RsaI, NdeII, NciI, Sau96I and ScrFI). The restriction profiles were compared to those of the type strains of $B$. cepacia (ATCC 25416 ${ }^{\mathrm{T}}$ ), Burkholderia glathei (LMG 14190 ${ }^{\mathrm{T}}$ ), B. vietnamiensis (LMG 10929 $)$, Burkholderia pyrrocinia (LMG 14191 ${ }^{\mathrm{T}}$ ), Burkholderia caryophylli (LMG 2155 ), Burkholderia glumae (LMG 2196 ${ }^{\mathrm{T}}$ ), Burkholderia gladioli $\left(\right.$ LMG 2216 $6^{\mathrm{T}}$ ), Burkholderia plantarii $\left(\mathrm{LMG} 9035^{\mathrm{T}}\right)$, Burkholderia cocovenenans (LMG $11626^{\mathrm{T}}$ ), Burkholderia andropogonis (LMG $2129^{\mathrm{T}}$ ) and B. graminis $\left(\mathrm{C}_{4} \mathrm{DIM} \mathrm{M}^{\mathrm{T}}\right)$.

PCR product direct sequencing. PCR products were purified on a $1 \%$ low-melting-point agarose gel and directly sequenced according to the protocol of Anderson et al. (1992). Seven primers were used in the sequencing reaction. These primers corresponded to the following positions in the E. coli rrs sequence: primer S3 (position 242-262), S6 (518-534), S8 (684-702), S10 (906-925), S12 (1099-1114), S15 (1384-1400) and S17 (1493-1509). Sequence reaction mixtures were subjected to electrophoresis on a $6 \%(\mathrm{w} / \mathrm{v})$ polyacrylamide sequencing gel in a Beckman Genomyx DNA sequencer.

Phylogenetic analysis. rrs sequences from strains MWAP64 ${ }^{\mathrm{T}}$, MWAP71 and MWAP84 were aligned and analysed by comparison to a personal database of already aligned and classified sequences (about 7000). The new sequences were manually aligned over more and more divergent domains as successive phylogenetic analyses (neighbour-joining) assigned these sequences to more precise clades. When a definitive identification to Burkholderia was obtained, three phylogenetic methods were used to assess very precisely the exact phylogenetic position of these sequences: the neighbour-joining method of Saitou \& Nei (1987), the maximumlikelihood method (options QFYG; FDNAML program of G. J. Olsen, University of Illinois, Urbana, IL, USA) and the maximum-parsimony method [PAUP program of D. Swofford (phylogenetic analysis using parsimony, version 3.0, distributed by the Illinois Natural History Survey, Champaign, IL, USA) for the Macintosh, heuristic search)]. The robustness of each topology was checked with the neighbour-joining method and 500 bootstrap replications using a Kimura two-parameter correction for computing distances. Trees were drawn with the NJPLOT program for the Macintosh (M. Gouy, CNRS UMR 5558, Université Claude Bernard, Lyon, France). Because all the sequences of strains shown in Fig. 1 are closely related, almost the entire sequences could be used to construct the dendrogram (positions 115-1376, E. coli numbering). 
Table 1. Strains investigated in this study, their origin and $r$ rs sequence accession number

\begin{tabular}{|c|c|c|}
\hline Strain* & Origin/reference & GenBank no. \\
\hline \multicolumn{3}{|c|}{ New isolates to be included in B. caribensis } \\
\hline MWAP53 & Vertisol (Martinique), this study & \\
\hline MWAP54 & Vertisol (Martinique), this study & \\
\hline MWAP55 & Vertisol (Martinique), this study & \\
\hline MWAP62 & Vertisol (Martinique), this study & \\
\hline MWAP64 $^{\mathrm{T}}\left(\right.$ LMG $\left.18531^{\mathrm{T}}\right)$ & Vertisol (Martinique), this study & Y17009† \\
\hline MWAP65 & Vertisol (Martinique), this study & \\
\hline MWAP67 & Vertisol (Martinique), this study & \\
\hline MWAP70 & Vertisol (Martinique), this study & \\
\hline MWAP71 & Vertisol (Martinique), this study & Y17010† \\
\hline MWAP74 & Vertisol (Martinique), this study & \\
\hline MWAP75 & Vertisol (Martinique), this study & \\
\hline MWAP76 & Vertisol (Martinique), this study & \\
\hline MWAP77 & Vertisol (Martinique), this study & \\
\hline MWAP78 & Vertisol (Martinique), this study & \\
\hline MWAP81 & Vertisol (Martinique), this study & \\
\hline MWAP82 & Vertisol (Martinique), this study & \\
\hline MWAP83 & Vertisol (Martinique), this study & \\
\hline MWAP84 (LMG 18532) & Vertisol (Martinique), this study & Y17011† \\
\hline MWAP85 & Vertisol (Martinique), this study & \\
\hline MWAP86 & Vertisol (Martinique), this study & \\
\hline MWAP87 & Vertisol (Martinique), this study & \\
\hline \multicolumn{3}{|l|}{ Reference strains } \\
\hline Burkholderia sp. LB400 & - & U86373 \\
\hline Burkholderia sp. N3P2 & Phenanthrene-enriched soil (Mueller et al., 1997) & U37344 \\
\hline Burkholderia sp. N2P5 & Phenanthrene-enriched soil (Mueller et al., 1997) & U37342 \\
\hline Burkholderia sp. N2P6 & Phenanthrene-enriched soil (Mueller et al., 1997) & U37340 \\
\hline Burkholderia sp. CRE7 & Phenanthrene-enriched soil (Mueller et al., 1997) & U37343 \\
\hline Burkholderia sp. GSOY & - & U16140 \\
\hline Burkholderia sp. VUN100313 & - & AF068011 \\
\hline Burkholderia sp. SAP II & - & AF052387 \\
\hline B. glathei LMG $14190^{\mathrm{T}}$ & Germany (Zolg \& Ottow, 1975) & Y17052† \\
\hline B. cepacia ATCC $25416^{\mathrm{T}}$ & Allium cepa (Ballard et al., 1970) & U96927 \\
\hline B. vietnamiensis $\mathrm{LMG} 10929^{\mathrm{T}}$ & Rice rhizosphere, Vietnam (Gillis et al., 1995) & U96928 \\
\hline B. pyrrocinia $\mathrm{LMG} 14191^{\mathrm{T}}$ & Unknown (Imanaka et al., 1965) & U96930 \\
\hline B. caryophylli LMG $2155^{\mathrm{T}}$ & Dianthus caryophillus (Ballard et al., 1970) & X67039 \\
\hline B. glumae LMG $2196^{\mathrm{T}}$ & Oryza sativa, Japan & U96931 \\
\hline B. gladioli LMG $2216^{\mathrm{T}}$ & Gladiolus sp., USA (Severini, 1913) & X67038 \\
\hline B. plantarii LMG $9035^{\mathrm{T}}$ & Oryza sativa, Japan (Azegami et al., 1987) & U96933 \\
\hline B. cocovenenans $\mathrm{LMG} 11626^{\mathrm{T}}$ & Fermented coconut, Java (Vandamme et al., 1960) & U96934 \\
\hline B. andropogonis LMG $2129^{\mathrm{T}}$ & Sorghum bicolor (Stapp, 1935) & $\mathrm{X} 67037$ \\
\hline B. phenazinium LMG $2247^{\mathrm{T}}$ & Soil (Bell \& Turner, 1973) & U96936 \\
\hline B. graminis C4DIM ${ }^{\mathrm{T}}$ & Maize rhizosphere, France (Viallard et al., 1998) & U96939 \\
\hline Burkholderia sp. m35b & Maize rhizosphere, France (Viallard et al., 1998) & U96937 \\
\hline Burkholderia sp. C3B1M & Maize rhizosphere, France (Viallard et al., 1998) & U96938 \\
\hline B. thailandensis E264 & Environmental isolate (Brett et al., 1997) & U91838 \\
\hline B. pseudomallei $1026 \mathrm{~b}$ & Environmental isolate (Brett et al., 1997) & U91839 \\
\hline B. vandii LMG $16020^{\mathrm{T}}$ & Orchid rhizosphere (Urakami et al., 1994) & U96932 \\
\hline Burkholderia sp. JB1 & Garden soil (Springael et al., 1996) & $\mathrm{X} 92188$ \\
\hline
\end{tabular}

*ATCC, American Type Culture Collection, Manassas, VA, USA; LMG, Laboratorium Microbiologie Gent Culture Collection, Universiteit Gent, Gent, Belgium.

$\dagger$ Sequences determined in this study. 
DNA-DNA hybridization. Genomic DNAs were extracted from the isolates and purified (Brenner et al., 1982). DNA purity was monitored by measuring absorbance at 230,260 and $280 \mathrm{~nm}$ (Genequant, Pharmacia). Genomic DNAs were sheared by sonication to produce a mean fragment size of $0 \cdot 4 \mathrm{~kb}$. DNA was labelled with $\left[1^{\prime}, 2^{\prime}, 5-{ }^{3} \mathrm{H}\right] \mathrm{dATP}$ (Amersham) by nick translation with a commercial kit as recommended by Amersham. Labelled DNAs were prepared from strain MWAP64 ${ }^{T}$. DNA reassociation experiments were performed in triplicate in $300 \mu \mathrm{l} 0.42 \mathrm{M} \mathrm{NaCl}$ containing $75 \mu \mathrm{g}$ sheared, denatured unlabelled DNA and $0.07 \mu \mathrm{g}$ denatured labelled DNA, under stringent conditions $\left(70^{\circ} \mathrm{C}\right)$ according to the S1 nuclease-TCA method (Crosa et al., 1973; Grimont et al., 1980).

DNA base composition. The $\mathrm{G}+\mathrm{C}$ content of strain MWAP71 was determined by the thermal denaturation method (Marmur \& Doty, 1962) and was calculated by using the equation of Owen \& Lapage (1976).

\section{RESULTS AND DISCUSSION}

\section{Localization and phenotypic identification of the major EPS-producing MWAP strains}

After fractionation of the vertisol, total cultivable bacteria were counted on tenfold-diluted TSA medium in different fraction sizes : $<5 \mu \mathrm{m}, 5-20 \mu \mathrm{m}, 20-50 \mu \mathrm{m}$, $50-250 \mu \mathrm{m}$ and $>250 \mu \mathrm{m}$. The $5-20 \mu \mathrm{m}$ fraction was described by Kabir et al. (1994) as the bacteriaenriched fraction in this soil. This was confirmed in this study and the cultivable bacteria population was estimated to be $5 \times 10^{7}$ c.f.u. (g dry soil) ${ }^{-1}$ in the 5-20 $\mu \mathrm{m}$ fraction. The $21 \mathrm{MWAP}$ strains that were isolated from the 5-20 $\mu \mathrm{m}$ fraction of the vertisol were identified as $B$. cepacia or as $B$. glathei by using BIOLOG Gram-negative microplates.

\section{ARDRA}

The rrs gene of the 21 MWAP strains and the 11 type strains of Burkholderia species were mapped with 12 restriction enzymes. The 21 MWAP strains provided exactly the same profiles with the tested restriction enzymes and belonged to a single ARDRA group. However, differences were observed with previously described species of Burkholderia (B. cepacia ATCC $25416^{\mathrm{T}}$, B. glathei $\mathrm{LMG} 14190^{\mathrm{T}}$, B. vietnamiensis $\mathrm{LMG}$ $10929^{\mathrm{T}}$, B. pyrrocinia LMG $14191^{\mathrm{T}}, B$. caryophylli LMG $2155^{\mathrm{T}}, B$. glumae LMG $2196^{\mathrm{T}}$, B. plantarii LMG $9035^{\mathrm{T}}$, B. cocovenenans LMG $11626^{\mathrm{T}}$, B. andropogonis LMG $2129^{\mathrm{T}}$, Burkholderia phenazinium LMG $2247^{\mathrm{T}}$ and $B$. graminis $\mathrm{C}_{4} \mathrm{DIM}^{\mathrm{T}}$ ) and at least five different profiles corresponding to five restriction enzymes were obtained for the closest species $B$. graminis.

\section{rrs sequences and phylogenetic analyses}

To perform a phylogenetic identification, rrs sequences of strains MWAP64 ${ }^{\mathrm{T}}$, MWAP71 and MWAP84 were analysed. The results of broad phylogenetic analyses clearly showed that these strains belonged to the phylum Proteobacteria of the eubacteria (data not

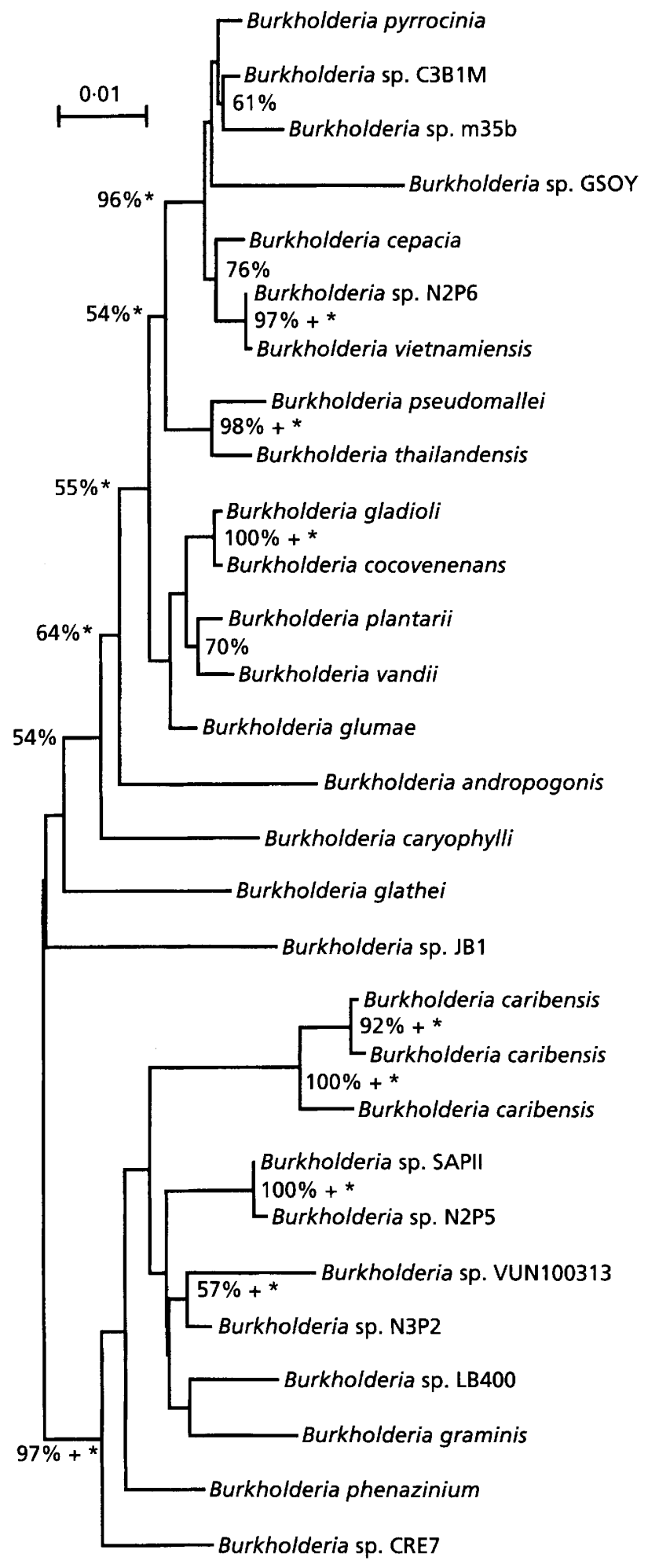

Fig. 1. Unrooted phylogenetic tree of Burkholderia 165 rDNA sequences. This topology was obtained using all known complete or almost complete sequences from Burkholderia strains (see Table 1). The topology shown was obtained by neighbour-joining, the percentage values indicating the results of a bootstrap analysis (500 replications, only values above $50 \%$ are indicated). Congruences with maximum-likelihood and maximum-parsimony analyses are shown by * $(P<0.01$ for $M L)$ and + , respectively. 
Table 2. DNA-DNA reassociation values between vertisol microaggregate MWAP isolate DNA and DNA of $B$. cepacia, B. glathei and B. graminis type strains

\begin{tabular}{|lc|}
\hline Strain* & $\begin{array}{c}\text { Percentage DNA relatedness } \\
\text { with } \text { B. caribensis } \text { MWAP64 } \\
\end{array}$ \\
\hline MWAP64 & 100 \\
MWAP84 & $105 \pm 2$ \\
MWAP53 & $80 \pm 1$ \\
MWAP71 & $74 \pm 3$ \\
B. glathei LMG $14190^{\mathrm{T}}$ & $11 \pm 7$ \\
B. cepacia ATCC $25416^{\mathrm{T}}$ & $2 \pm 1$ \\
B. graminis C4DIM ${ }^{\mathrm{T}}$ & $18 \pm 13$ \\
\hline
\end{tabular}

* DNA used as template.

$\dagger$ DNA used as probe. DNA reassociation values are mean values \pm SD obtained from two independent experiments.

shown) and, more precisely, to the $\beta$-subclass. More detailed analyses showed that they were included in the Burkholderia genus. Three phylogenetic methods were then used (neighbour-joining, maximum-likelihood and maximum-parsimony), each of which grouped all of the Burkholderia sequences in a monophyletic taxon. All three MWAP strains formed a robust monophyletic unit (Fig. 1). Although we did not perform extensive DNA-DNA hybridization with each recognized Burkholderia species, such analyses were done for the most closely related species (Table 2). MWAP strains can be considered as a new species, different from the other Burkholderia species for the following reasons: (i) they constitute a line of descent that cannot be grouped with any recognized species, (ii) they show $r r s$ sequence divergence of more than $3 \%$ from any recognized species (Stackebrandt \& Goebel, 1994) and (iii) they have a very low level of DNA-DNA similarity with type strains of phylogenetically related species. Phylogenetically, B. caribensis is included in a robust clade containing two recognized species (B. phenazinium and $B$. graminis) and several strains not yet recognized as species, among which are Burkholderia sp. strain LB400, a polychlorinated biphenyl-degrading strain (U86373), and Burkholderia sp. strains N3P2 (U37344) and N2P5 (U37342), phenanthrene-degrading bacteria (Mueller et al., 1997). The robustness of the clade suggests that other strains of this cluster may have similar degrading properties. Finally, except for strains N2P5, SAP II (AF052387) and B. caribensis strains, not even two of the other sequences could be grouped in a robust subclade, suggesting that they may all be different species (Fig. 1).

\section{DNA-DNA hybridization}

Values for DNA-DNA reassociation data are shown in Table 2. High levels of DNA homology were detected between strains MWAP64 ${ }^{\mathrm{T}}$, MWAP84, MWAP53 and MWAP71 (ranging from 74 to $105 \%$ ).
In contrast, the DNA hybridization values between MWAP strains and the type strains of $B$. cepacia, $B$. graminis and $B$. glathe $i$ were low and ranged from 1 to $20 \%$ (Table 2).

\section{Phenotypic and physiological characteristics of MWAP strains}

The 21 MWAP strains were Gram-negative, pleiomorphic rods, $1-2 \mu \mathrm{m}$ long and $0.5 \mu \mathrm{m}$ in diameter. They formed smooth white colonies with regular edges when grown overnight on TSA medium at $28^{\circ} \mathrm{C}$ and mucoid colonies due to EPS production on sugarenriched media. No production of diffusible or fluorescent pigment on TSA and Pseudomonas $\mathrm{F}$ agar media was observed. On PCAT medium, these strains formed white colonies, smaller than those of B. cepacia. Optimal growth was observed at $28^{\circ} \mathrm{C}$.

Table 3 shows the biochemical characters tested on BIOLOG GN and GP microplates which differentiated MWAP strains from the following closely related Burkholderia species (as defined according to $r r s$ sequencing and ARDRA data): $B$. glathei, $B$. graminis, B. phenazinium, B. caryophylli and B. andropogonis.

\section{Conclusion}

Besides the proposal of a new name, Burkholderia caribensis sp. nov., two major conclusions on habitat and activity of this species can be drawn: (i) because of the physical fractionation of soil samples and the selection of the 5-20 $\mu \mathrm{m}$ fraction for isolation steps, it can be concluded that strains of this species were present in the core of microaggregates, and (ii) it constituted the dominant cultivable population in this soil fraction as revealed on carbon-rich medium. Unlike most of the Burkholderia strains isolated from various environments, the Burkholderia strains described in this study were not isolated on PCAT medium. The main objective of this study was to isolate the dominant EPS-producing bacterial species and not especially Burkholderia strains. However, these strains were able to grow on PCAT medium as most of the Burkholderia species did. The capacity of each strain of this species to produce high amounts of EPS on carbon-rich medium was confirmed in pure cultures supplemented with various carbohydrates.

Several phenotypic characteristics differentiated the MWAP isolates from the most closely phylogenetically related Burkholderia species (B. glathei, B. graminis, $B$. phenazinium, $B$. caryophylli and $B$. andropogonis). The MWAP isolates were unable to oxidize malonic acid on BIOLOG GN microplates, in contrast to the five tested Burkholderia species. According to $r$ rs sequence analysis, $B$. graminis was the most closely related species ( $97 \%$ similarity) and eight biochemical characters enabled differentiation of this species from MWAP strains: oxidation of sucrose, D-raffinose, $\alpha$-keto- 
Table 3. Biochemical characters that differentiate B. glathei, B. andropogonis, B. caryophylli, B. phenazinium and $B$. graminis from MWAP isolates

BIOLOG data of B. glathei, B. andropogonis, B. caryophylli, and B. phenazinium were provided by G. Bochner and J. Young from BIOLOG Inc. $n$, Number of strains; + , all strains positive; - , all strains negative; $(+), 50-90 \%$ strains positive; $(-), 8-25 \%$ strains positive; ND, not determined.

\begin{tabular}{|c|c|c|c|c|c|c|}
\hline Characteristic & $\begin{array}{l}\text { B. caribensis } \\
\quad(n=21)\end{array}$ & $\begin{array}{l}\text { B. graminis } \\
\left.\text { (C4DIM }{ }^{\mathrm{T}}\right)\end{array}$ & $\begin{array}{c}\text { B. phenazinium } \\
(n=3)\end{array}$ & $\begin{array}{l}\text { B. caryophylli } \\
(n=12)\end{array}$ & $\begin{array}{c}\text { B. andropogonis } \\
(n=16)\end{array}$ & $\begin{array}{c}\text { B. glathei } \\
(n=16)\end{array}$ \\
\hline D-Trehalose & + & + & - & $(+)$ & - & - \\
\hline Sucrose & - & + & + & + & - & - \\
\hline D-Raffinose & - & + & - & - & - & - \\
\hline$\alpha$-Ketovaleric acid & + & - & + & - & - & + \\
\hline Malonic acid & - & + & $(+)$ & + & + & + \\
\hline$N$-Acetylmannosamine & + & - & ND & ND & ND & $\mathrm{ND}$ \\
\hline Lactamide & + & - & ND & ND & ND & ND \\
\hline AMP & + & - & $\mathrm{ND}$ & ND & ND & ND \\
\hline Glycyl-L-aspartic acid & - & - & + & $(+)$ & - & $(+)$ \\
\hline Glucoronamide & + & + & - & $(-)$ & $(+)$ & $(+)$ \\
\hline DL-Carnitine & + & + & - & - & - & $(+)$ \\
\hline L-Ornithine & $(-)$ & + & $(+)$ & $(+)$ & - & $(-)$ \\
\hline Lactose & - & + & - & - & $(-)$ & + \\
\hline
\end{tabular}

valeric-acid, $N$-acetylmannosamine, lactamide, AMP, L-ornithine and lactose (Table 3).

The data from rrs sequences, ARDRA and DNADNA hybridization revealed that these EPS-producing bacteria formed a monophyletic unit in the genus Burkholderia. rrs sequence divergence, DNA-DNA hybridization data and biochemical characters allow the description of a new species for which we propose the name Burkholderia caribensis sp. nov.

\section{Description of Burkholderia caribensis sp. nov.}

Burkholderia caribensis (ca.ri.ben'sis. M.L. adj. caribensis pertaining to the Caribbean Islands, named after the once-indigenous Caribe Indians, where the strains were isolated).

Cells are short rods $(1-2 \times 0.5 \mu \mathrm{m})$, Gram-negative, motile and pleiomorphic in actively growing cultures (LB medium). Cells produce large amounts of EPS when grown on sugar-enriched agar media $(2 \%$ glucose, xylose, fructose, sorbitol, arabinose, xylose, mannitol or inositol). Colonies are about $3 \mathrm{~mm}$ in diameter after $24 \mathrm{~h}$ incubation on tenfold-diluted TSA medium at $28{ }^{\circ} \mathrm{C}$. They are white, smooth and mucoid. No diffusible or fluorescent pigment was observed. Oxidase, catalase, urease, arginine dihydrolase and $\beta$ galactosidase are produced but protease is not produced. The following are oxidized: Tweens 40 and 80 , $N$-acetyl-D-galactosamine, adonitol, L-arabinose, Darabitol, D-fructose, L-fucose, D-galactose, $\alpha$-D-glucose, myo-inositol, $\alpha$-lactose, lactulose, maltose, Dmannitol, D-mannose, psicose, L-rhamnose, D-sorbitol,
D-trehalose, xylitol, methylpyruvate, monomethylsuccinate, cis-aconitic acid, citric acid, formic acid, Dgalactonic acid lactone, D-galacturonic acid, D-gluconic acid, D-glucosaminic acid, D-glucoronic acid, $\alpha$ hydroxybutyric acid, $\beta$-hydroxybutyric acid, $p$-hydroxyphenylacetic acid, $\alpha$-ketobutyric acid, $\alpha$-ketoglutaric acid, $\alpha$-ketovaleric acid, DL-lactic acid, quinic acid, D-saccharic acid, sebatic acid, succinic acid, bromosuccinic acid, succinamic acid, glucoronamide, alaninamide, D-alanine, L-alanine, L-alanylglycine, Lasparagine, L-aspartic acid, L-glutamic acid, glycyl-Lglutamic acid, L-histidine, hydroxy-L-proline, L-ornithine, L-phenylalanine, L-proline, L-pyroglutamic acid, D-serine, L-threonine, DL-carnitine, $\gamma$-aminobutyric acid, urocanic acid, inosine, 2-aminoethanol, 2,3butanediol, glycerol, DL- $\alpha$-glycerol phosphate, glucose 6-phosphate, $N$-acetyl-D-gluconic acid, lactulose, palatinose, D-ribose, salicin, D-tagatose, D-xylose, lactamide, D-lactic acid methyl ester, D-malic acid, Lmalic acid, pyruvic acid, $N$-acetyl-L-glutamic acid, adenosine, $2^{\prime}$-deoxyadenosine, AMP, fructose 6-phosphate, $\mathrm{N}$-acetylglucosamine, gluconate, caprate, malate, citrate and phenylacetate. Arginine dihydrolase, urease and $\beta$-galactosidase are produced. The following are not oxidized: $\alpha$-cyclodextrin, $N$-acetyl-Dgalactosamine, cellobiose, $i$-erythritol, gentiobiose, $\alpha$ lactose, melibiose, $\beta$-methyl-D-glucoside, D-raffinose, sucrose, turanose, malonic acid, glycyl-L-aspartic acid, inulin, amygdalin, arbutin, $\alpha$-D-lactose, maltotriose, Dmelezitose, 3 -methylglucose, $\alpha$-methyl-D-glucoside, $\beta$ methyl-D-mannoside, palatinose, stachyose, TMP, UMP, nitrate, tryptophan, esculin and adipate. The $\mathrm{G}+\mathrm{C}$ content is $63.1 \mathrm{~mol} \%$. The type strain of Burkholderia caribensis is MWAP64 ${ }^{\mathrm{T}}$ which has been deposited in the BCCM/LMG Culture Collection as 
LMG $18531^{\mathrm{T}}$. The characteristics of this strain are identical to those described above for the species.

\section{ACKNOWLEDGEMENTS}

This work was supported by a grant from ORSTOM, CNRS, INRA and CIRAD in a framework of 'Action Incitative InterInstitutionnelle' entitled 'Biofonctionnement des sols tropicaux et gestion durable des terres'. We gratefully acknowledge Dr L. Sutra for G+C content determination and Drs G. Bochner and J. Young from BIOLOG Inc. for providing BIOLOG data on Burkholderia species.

\section{REFERENCES}

Anderson, R. D., Bao, C.-Y. , Minnick, D. T., Veigel, M. \& Sedwick, W. D. (1992). Optimization of double-stranded DNA sequencing for polymerase chain reaction products. USB Edit Comment 19, $39-40$ and 57-58.

Azegami, K., Nishiyama, K., Watanabe, Y., Kadota, I., Ophuchi, A. \& Fukazawa, C. (1987). Pseudomonas plantarii sp. nov., the causal agent of rice seedling blight. Int $J$ Syst Bacteriol 37, 144-152.

Ballard, R. W., Palleroni, N. J., Stanier, R. Y. \& Mandel, M. (1970). Taxonomy of aerobic pseudomonads $P$ seudomonas cepacia, $P$. marginata, $P$. alliicola and $P$. caryophylli. J Gen Microbiol 60 , 199-214.

Bell, S. C. \& Turner, J. M. (1973). Iodinin biosynthesis by a pseudomonad. Biochem Soc Trans 1, 751-753.

Brenner, D. J., McWorter, A. C., Leete Knutson, J. K. \& Steigerwalt, A. G. (1982). Escherichia vulneris: a new species of Enterobacteriaceae associated with human wounds. $J$ Clin Microbiol 15, 1133-1140.

Brett, P. J., DeShazer, D. \& Woods, D. E. (1997). Characterization of Burkholderia pseudomallei and Burkholderia pseudomalleilike strains. Epidemiol Infect 118, 137-148.

Brett, P. J., DeShazer, D. \& Woods, D. E. (1998). Burkholderia thailandensis sp. nov., a Burkholderia pseudomallei-like species. Int J Syst Bacteriol 48, 317-320.

Crosa, J. M., Brenner, D. J. \& Falkow, S. (1973). Use of a single strand-specific nuclease for analysis of bacterial and plasmid deoxyribonucleic acid homo- and heteroduplexes. $J$ Bacteriol 115, 904-911.

De Vos, P., Goor, M., Gillis, M. \& De Ley, J. (1985). Ribosomal ribonucleic acid cistron similarities of phytopathogenic Pseudomonas species. Int J Syst Bacteriol 35, 169-184.

Gillis, M., Tran Van, V., Bardin, R., Goor, M., Hebbar, P., Willems, A., Sergers, P., Kersters, K., Heulin, T. \& Fernandez, M. (1995). Polyphasic taxonomy in the genus Burkholderia leading to an emended description of the genus and proposition of Burkholderia vietnamiensis $\mathrm{sp}$. nov. for $\mathrm{N}_{2}$-fixing isolates from rice in Vietnam. Int $J$ Syst Bacteriol 45, 274-289.

Grimont, P. A. D., Popoff, M. Y., Grimont, F., Coynault, C. \& Lemelin, M. (1980). Reproducibility and correlation study of three deoxynucleic acid hybridization procedure. Curr Microbiol 4, 325-330.

Hebbar, K. P., Davey, A. G. \& Dart, P. J. (1992a). Rhizobacteria of maize antagonistic to Fusarium moniliforme, a soil-borne fungal pathogen: identification and isolation. Soil Biol Biochem 24, 989-997.

Hebbar, K. P., Davey, A. G., Merrin, J. \& Dart, P. J. (1992b).
Pseudomonas cepacia, a potential suppresser of maize soilborne diseases: seed inoculation and maize root colonization. Soil Biol Biochem 24, 999-1007.

Imanaka, H., Kousaka, M., Tamura, G. \& Arima, K. (1965). Studies on pyrrolnitrin, a new antibiotic. Taxonomy studies on pyrrolnitrin-producing strain. J Antibiot 18, 205-206.

Kabir, M., Chotte, J. L., Rahman, M., Bally, R. \& JocteurMonrozier, L. (1994). Distribution of soil fractions and location of soil bacteria in a vertisol under cultivation and perennial grass. Plant Soil 163, 243-255.

Kersters, K., Ludwig, W., Vancanneyt, M., De Vos, P., Gillis, M. \& Schleifer, K.-H. (1996). Recent changes in the classification of the Pseudomonas: an overview. Syst Appl Microbiol 19, 465-467.

Lumsden, R. D. \& Sasser, M. (1986). Medium for the isolation of Pseudomonas cepacia biotype from soil and the bacterial biotype. US Patent no. 4.588.584.

Marmur, J. \& Doty, P. (1962). Determination of the base composition of deoxyribonucleic acid from its thermal denaturation temperature. J Mol Biol 5, 109-118.

Migula, W. (1894). Arbeiten aus dem Bacteriologischen Institut der Technischen Hochschule zu Karlsruhe 1, 235-238.

Mueller, J. G., Devereux, R., Santavy, D. L., Lantz, S. E., Willis, S. G. \& Pritchard, P. H. (1997). Phylogenetic and physiological comparisons of PAH-degrading bacteria from geographically diverse soils. Antonie Leeuwenhoek 71, 329-343.

Owen, R. J. \& Lapage, S. P. (1976). The thermal denaturation of partly purified bacterial deoxyribonucleic acid and its taxonomic implications. J Appl Bacteriol 41, 335-340.

Palleroni, N. J. (1984). Genus Pseudomonas Migula $1894237^{\mathrm{AL}}$ In Bergey's Manual of Systematic Bacteriology, vol. 1, pp. 141-199. Edited by N. R. Krieg \& J. G. Holt. Baltimore: Williams \& Wilkins.

Palleroni, N. J. (1992). Present situation in the taxonomy of aerobic pseudomonads. In Pseudomonas: Molecular Biology and Biotechnology, pp. 105-115. Edited by E. Gali, S. Silver \& B. Wit. Washington, DC: American Society for Microbiology. Palleroni, N. J., Kunisawa, R., Contopoulou, R. \& Doudoroff, M. (1973). Nucleic acid homologies in the genus Pseudomonas. Int $J$ Syst Bacteriol 23, 333-339.

Saitou, N. \& Nei, M. (1987). The neighbor-joining method: a new method for reconstructing phylogenetic trees. Mol Biol Evol 4, 406-425.

Segers, P., Vancanneyt, M., Pot, B., Torck, U., Hoste, B., Dewettinck, D., Falsen, E., Kersters, K. \& De Vos, P. (1994). Classification of Pseudomonas diminuta Leifson and Hugh 1954 and Pseudomonas vesicularis Büsing, Döll and Freytag 1953 in Brevundimonas gen. nov. as Brevundimonas diminuta comb. nov. and Brevundimonas vesicularis comb. nov., respectively. Int $J$ Syst Bacteriol 44, 499-510.

Severini, G. (1913). Una bacteriosi dell'Ixia maculata e del Gladiolus coluilli. Ann Bot (Rome) 11, 413-424.

Springael, D., van Thor, J., Goorissen, H., Ryngaert, A., De Baere, R., Van Hauwe, P., Commandeur, L. C., Parsons, J. R., De Wachter, R. \& Mergeay, M. (1996). RP4::Mu3A-mediated in vivo cloning and transfer of a chlorobiphenyl catabolic pathway. Microbiology 142, 3283-3293.

Stackebrandt, E. \& Goebel, B. M. (1994). A place for DNA-DNA reassociation and 16S rRNA sequence analysis in the present species definition in bacteriology. Int $J$ Syst Bacteriol 44, 846-849.

Stapp, C. (1935). Contemporary understanding of bacterial plant diseases and their causal organisms. Bot Rev 1, 405-418. 
Tisdall, J. M. (1994). Possible role of soil microorganisms in aggregation in soils. Plant Soil 159, 115-121.

Urakami, T., Ito-Yoshida, C., Araki, H., Kijima, T., Suzuki, K. I. \& Komagata, K. (1994). Transfer of Pseudomonas plantarii and Pseudomonas glumae to Burkholderia as Burkholderia spp. and description of Burkholderia vandii sp. nov. Int $J$ Syst Bacteriol 44, 235-245.

Vandamme, P., Johannes, A. G., Cox, H. C. \& Berends, W. (1960). On toxoflavin, the yellow poison of Pseudomonas cocovenenans. Recl Trav Chim Pays-Bas Belg 79, 255-267.

Vandamme, P., Holmes, B., Vancanneyt, M. \& 8 other authors (1997). Occurrence of multiple genomovars of Burkholderia cepacia in cystic fibrosis patients and proposal of Burkholderia multivorans sp. nov. Int J Syst Bacteriol 47, 1188-1200.

Viallard, V., Poirier, I., Cournoyer, B., Haurat, J., Wiebkin, S., Ophel-Keller, K. \& Balandreau, J. (1998). Burkholderia graminis sp. a novel species of rhizospheric Burkholderia species and reassessment of [Pseudomonas] phenazinium, [Pseudomonas] pyrrocinia and [Pseudomonas] glathei as Burkholderia. Int J Syst Bacteriol 48, 549-563.

Yabuuchi, E., Yano, I., Oyaizu, H., Hashimoto, Y., Ezaki, T. \& Yamamoto, H. (1990). Proposal of Sphingomonas paucimobilis gen. nov. and comb. nov., Sphingomonas parapaucimobilis sp. nov., Sphingomonas yanoikuyae sp. nov., Sphingomonas adhaesiva sp. nov., Sphingomonas capsulata comb. nov. and two genospecies of the genus Sphingomonas. Int J Syst Bacteriol 40, 99-119.

Yabuuchi, E., Kosako, Y., Oyaizu, H., Yano, I., Hotta, H., Hashimoto, Y., Ezaki, T. \& Arakawa, M. (1992). Proposal of Burkholderia gen. nov. and transfer of seven species of the genus Pseudomonas homology group II to the new genus, with the type species Burkholderia cepacia (Palleroni and Holmes 1981) comb. nov. Microbiol Immunol 36, 1251-1275.

Yabuuchi, E., Kosako, Y., Yano, I., Hotta, H. \& Nishiuchi, Y. (1995). Transfer of two Burkholderia and an Alcaligenes species to Ralstonia pickettii (Ralston, Palleroni and Doudoroff 1973) comb. nov., Ralstonia solanacearum (Smith 1896) comb. nov. and Ralstonia eutropha (Davis 1969) comb. nov. Microbiol Immunol 39, 897-904.

Yohalem, D. S. \& Lorbeer, J. W. (1994). Intraspecific metabolic diversity among strains of Burkholderia cepacia isolated from decayed onions, soils and the clinical environment. Antonie Leeuwenhoek 65, 111-131.

Zhao, N. X., Qu, C. F., Wang, E. T. \& Chen, W. X. (1995). Phylogenetic evidence for the transfer of Pseudomonas cocovenenans (van Damme et al. 1960) to the genus Burkholderia as Burkholderia cocovenenans (van Damme et al. 1960) comb. nov. Int $J$ Syst Bacteriol 45, 600-603.

Zolg, W. \& Ottow, J. C. G. (1975). Pseudomonas glathei sp. nov. A new nitrogen scavenging rod isolated from acid lateritic relicts in Germany. Z Allg Mikrobiol 15, 287-299. 